PERSPECTIVE

\title{
Apocalypse now: Australian bushfires and the future of urban settlements
}

\author{
Barbara Norman $\mathbb{D}^{1 凶}$, Peter Newman $\mathbb{D}^{2}$ and Will Steffen ${ }^{3}$
}

The apocalyptic Australian bushfires have challenged the way we plan settlements. What is the future for small urban settlements within fire-vulnerable forests and bushland? Could they create a new model for rural settlements with wider lessons for development in big cities? This paper draws together observations of the 2019/20 bushfire size, intensity and destructiveness and links the fires to the global nature of the climate crisis and an earlier case study that accurately predicted the fire impacts in southeast coastal Australia. The findings are set out in two scenarios suggesting that the fires can lead to a new model for climate resilient development that can flow into larger centres with multiple benefits.

npj Urban Sustainability (2021)1:2; https://doi.org/10.1038/s42949-020-00013-7

\section{THE AUSTRALIAN BUSHFIRES}

The Australian bushfires brought in the 2020s with a global sense of apocalypse. The extent, timing and intensity of the fires dramatically demonstrated how climate change is already driving catastrophic impacts ${ }^{1}$. The Intergovernmental Panel on Climate Change Reports have highlighted fire risk to Australia in every major report since $2001^{2-4}$ and Australia's own Garnaut Report in 2008 said prophetically '.....without adequate action, the nation will face a more frequent and intense fire season by $2020^{\prime 5}$. Nevertheless, the Australian delegation at the COP 26 Madrid climate change conference was part of the group of four nations attempting to reduce the Paris commitments in December 2019 even as the fires were spreading rapidly.

The IPSOS (2020) report $^{6}$ on Australian attitudes showed a dramatic increase in concern for the environment in January 2020, now the highest concern of all issues (see Fig. 1). The poll showed that 'citizens mostly attributed their worry to climate change, drought and bushfire' with a strong concern about the 'reluctance of government to be proactive' about this and other environmental concerns.

The 2019/2020 Australian fires resulted in the tragic loss of over 400 lives, 33 of them directly from the fires and 417 from smoke inhalation ${ }^{7}$. Over 3000 homes and 7000 facilities and outbuildings were destroyed; 12.6 million hectares burned; and over 100,000 head of stock lost ${ }^{8}$. Nearly 80 percent of Australians were affected either directly or indirectly by the fires ${ }^{9}$. Tragically, an estimated one billion native animals died ${ }^{10}$, a scenario almost unimaginable. The fires blanketed urban areas with heavy smoke. During January 2020, the national capital Canberra measured the worst air quality index of any major city in the world ${ }^{11}$.

These dramatic impacts across the Australian landscape are driving a deeper consideration of their implications for the future pattern of urban development. Australia is predominantly a coastal urban nation with $85 \%$ of the population living in the coastal zone and mostly in urban centres where there are significant areas of native forested bush. Such native bush is firedependent in its ecology so there has always been some awareness of the need for protection with a long history of volunteer fire brigades being a part of Australian settlements in such forested areas. However, the unprecedented ferocity of this fire season has traumatised Australia (Fig. 2). These deeper concerns have been called 'collective trauma' ${ }^{12}$, now magnified by the corona virus. It exposes Australians to reconsider how we live.

Here we examine how climate change-related bushfires now challenge the growth patterns of smaller regional centres across Australia, especially non metropolitan urban communities and the scattering of rural development into forest and along coastlines. Such development has much greater exposure to fire as well as often being heavily resource consumptive, so we need to urgently rethink how urban growth in these regional communities can be planned more sustainably in the future, perhaps setting a model for how larger cities can change ${ }^{13,14}$.

\section{THE APOCALYPSE DEFINED: BIOPHYSICAL TRENDS}

The apocalypse (as set out in Box 1) is caused by human civilization going beyond biophysical limits leading to collapse $e^{15}$. The apocalypse has been a part of much global ecological concern with accelerating climate change and the transgression of planetary boundaries ${ }^{16,17}$. Such a sense of apocalypse was associated with two features of the 2019/2020 eastern Australia fires - the unprecedented nature of the fires themselves and the key role that climate change played in driving them.

\section{The unprecedented nature of the fires}

The fires were unprecedented in several ways, most notably for their huge size. For example, the Gospers Mountain fire near Sydney burned over 500,000 ha, with massive impacts on the World Heritage forests (Fig. 3); this was the largest individual fire ever recorded in Australia ${ }^{18}$. The aggregated total area burnt was unprecedented, not only in an Australian context but also globally ${ }^{19}$. The area burned in eastern Australian eucalypt forests, well-known for being fire-prone, is only $2 \%$ or less on average, even in extreme fire seasons, similar to the average areas burned of temperate broad-leaf forests on other continents, where the fraction is well below $5 \%$ (apart from Africa and Asia, where the burn area can reach 8-9\%). However, the 2019/2020 eastern Australian fires consumed over $21 \%$ of the total forested area, an

${ }^{1}$ Canberra Urban and Regional Futures, Faculty of Arts and Design, University of Canberra, Canberra, Australia. ${ }^{2}$ Curtin University Sustainability Policy (CUSP) Institute, Curtin University, Perth, Australia. ${ }^{3}$ Fenner School of Environment and Society, Australian National University, Canberra, Australia. ${ }^{凶}$ email: barbara.norman@canberra.edu 


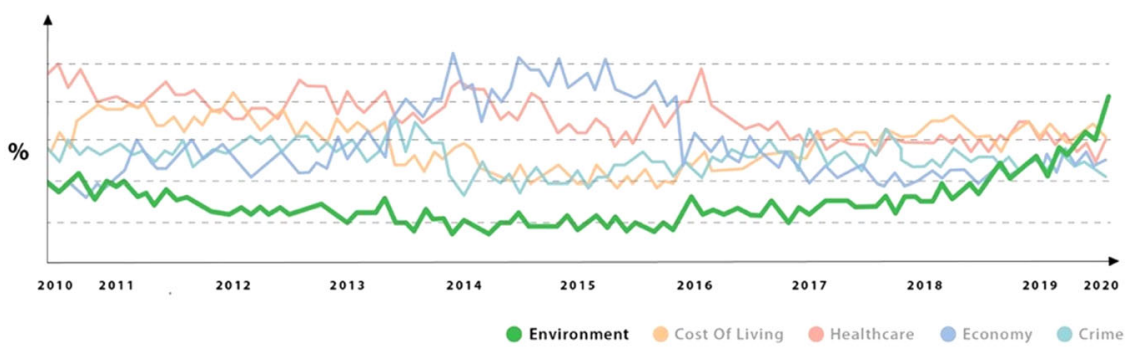

Fig. 1 Attitudes to major issues in Australia, 2010 to 2020 (IPSOS 2020). Green shows the rise of environmental concerns to highest \% during bushfires. Pollsters found the public linked fires to climate change and lack of action by government.

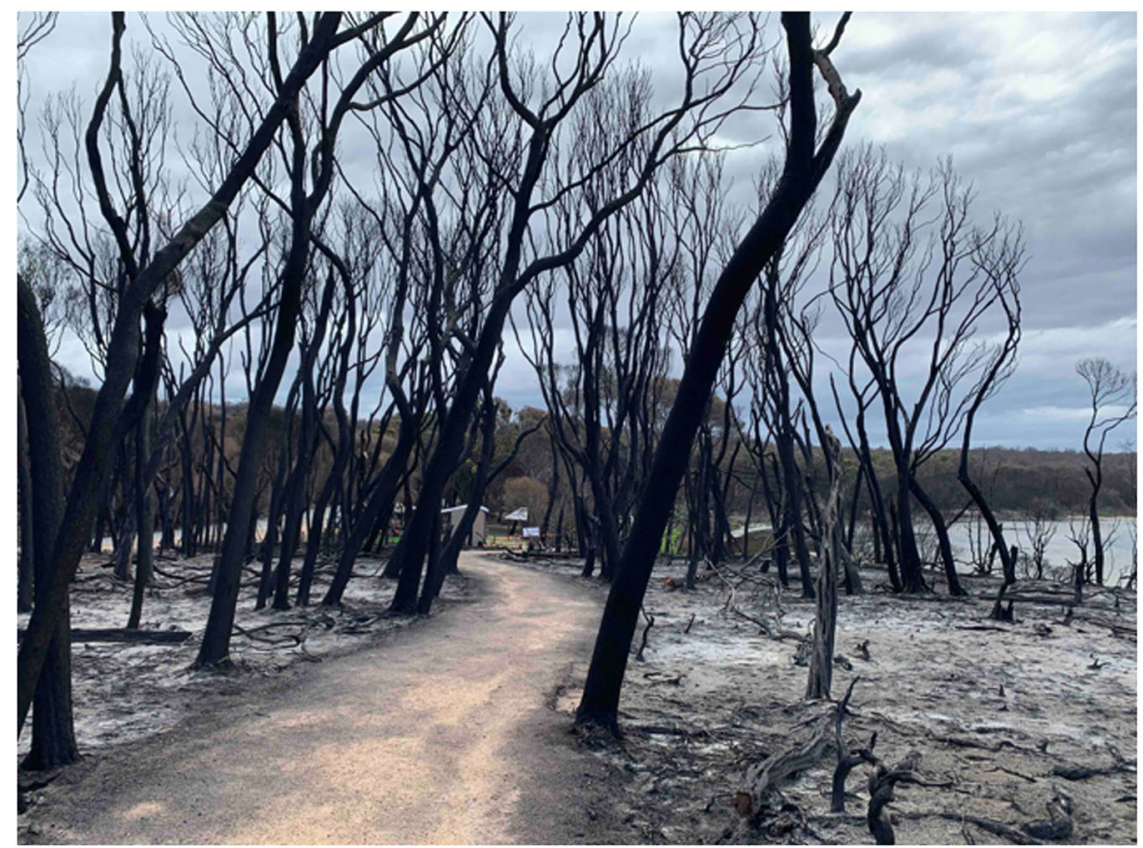

Fig. 2 Mallacoota fire impacted foreshore. Mallacoota, Victoria, Australia, Date 8 March 2020 (photo taken by Barbara Norman).

area far beyond anything previously experienced in Australia, or in the rest of the world.

The threats to urban areas from the massive fires were also unprecedented. On 12 November 2019, catastrophic fire danger weather was forecast for the Greater Sydney area, the first time ever the city itself has been directly threatened with such extreme fire conditions. Dense smoke blanketed Sydney for days, with the air quality index more than 12 times the hazardous level in parts of the city. Parts of Canberra registered an air quality index of 4650, more than 23 times the hazardous level, a level never seen before in that city. A state of emergency was declared for Canberra on 31 January 2020 as large fires burning in the mountains immediately south of the city threatened to force a mass evacuation of the southern suburbs and closed the airport for several days ${ }^{18}$.

Although the massive and destructive nature of the fires came as a shock to many, they were not unexpected for the scientific community. Climate and weather-based indicators used to assess dangerous fire weather also reinforced the unprecedented nature of the inferno. The Forest Fire Danger Index (FFDI), a composite indicator of bushfire weather, incorporates temperature, humidity, wind speed and antecedent conditions (e.g., longer-term rainfall that influences the condition of the vegetation). The FFDI reached record high levels in $2019^{20}$. As early as September 2019, well before the normal start of the bushfire season, catastrophic fire danger conditions (FFDI above 100) were recorded at several locations in $\mathrm{NSW}^{18}$.
Australia experienced its hottest year on record in 2019. The average maximum temperature was $2.09^{\circ} \mathrm{C}$ above the baseline, breaking $2{ }^{\circ} \mathrm{C}$ for the first time and a full $0.5^{\circ} \mathrm{C}$ higher than the previous record ${ }^{20} .2019$ was also the driest year on record for Australia, with rainfall across the continent a staggering $40 \%$ below the long-term average ${ }^{20}$, setting up the forests to burn. Fig. 4 shows the two-year deficit in rainfall across Australia, with most of the forested area along the east coast from southern Queensland to eastern Victoria experiencing its driest ever 2-year period ${ }^{21}$. The southwestern region of Australia has been drying for 40 years, linked to climate change, and in the last years has reverted to $60 \%$ dependence on desalinating seawater for the water supply of over two million residents in the Perth region ${ }^{22}$. Such long-term drying out of the landscape has also been occurring in the populous southeast over the past two to three decades.

\section{The link between the fires and climate change}

The conditions leading up to the 2019/2020 mega-fires were influenced by both longer-term trends of increasing extreme heat and less cool season rainfall in SE Australia, and by shorter-term modes of natural variability. The extreme dry conditions of 2019 have been linked to a very strong positive phase of the Indian Ocean Dipole (IOD), which leads to dry conditions across much of Australia. There is very likely a link between climate change and the unusual strength of the IOD in $2019^{23}$. According to paleo studies over the past 800 years, there have been 10 exceptionally 
strong IODs, and four of them have occurred during the last 60 years when human-driven climate change has been accelerating. Thus, the odds are increasing that even stronger IODs could occur in the future ${ }^{24}$.

The record high temperatures of 2019 were thus the latest in a multi-decadal trend of rising temperatures, driven by climate change $^{25}$. The recent very dry conditions are part of a longer-term trend of decreasing cool season rainfall over southeast Australia in

Box 1. The apocalypse in history

The apocalypse is about cataclysmic change symbolising the end times. It has been a part of Jewish literature since the Babylonian era ${ }^{68}$, in Muslim literature ${ }^{69}$ and in the Christian era is set out in the book of Revelation during the collapse of the Roman era. This involved four horsemen that symbolised: pandemics, famine from climate change, war (continuous conflict) and death (of civilization). Such ideas have been used in the past two thousand years to portray starkly different futures through art and literature ${ }^{70,71}$. The future was portrayed as a cataclysmic choice between two cities that were based either on frivolous consumption that would collapse from the four horsemen or on long term meaningful work (represented by building the city from diamonds, in harmony with the Tree of Life and River of Life) $)^{72}$. the past two to three decades-a decrease of about $15 \%$ in late autumn and early winter rainfall since the mid-1990s ${ }^{26}$, a trend that has been linked to climate change ${ }^{25}$.

In summary, there is strong evidence that climate change has played a key role in the size, intensity and destructiveness of the 2019/2020 eastern Australian bushfires. The fundamental physics of bushfire dynamics and climate change, backed up by observational and paleo evidence, suggest that the magnitude and ferocity of the 2019/2020 fires would have been virtually impossible without climate change.

\section{THE GROWING APOCALYPSE: URBAN SUSTAINABILITY AND 1.5 DEGREES}

Cities, the biggest source of greenhouse house gas emissions, are growing rapidly across the world. The Intergovernmental Panel on Climate Change (IPCC) now focuses on cities in the AR5, AR6 and the $1.5^{\circ} \mathrm{C}$ Special Report ${ }^{27-29}$.

One of the key ideas being used to explain how hard it is to find effective solutions to climate change is the notion of 'lock-in', a

\section{AREA BURNED IN THE BLUE MOUNTAINS WORLD HERITAGE AREA}

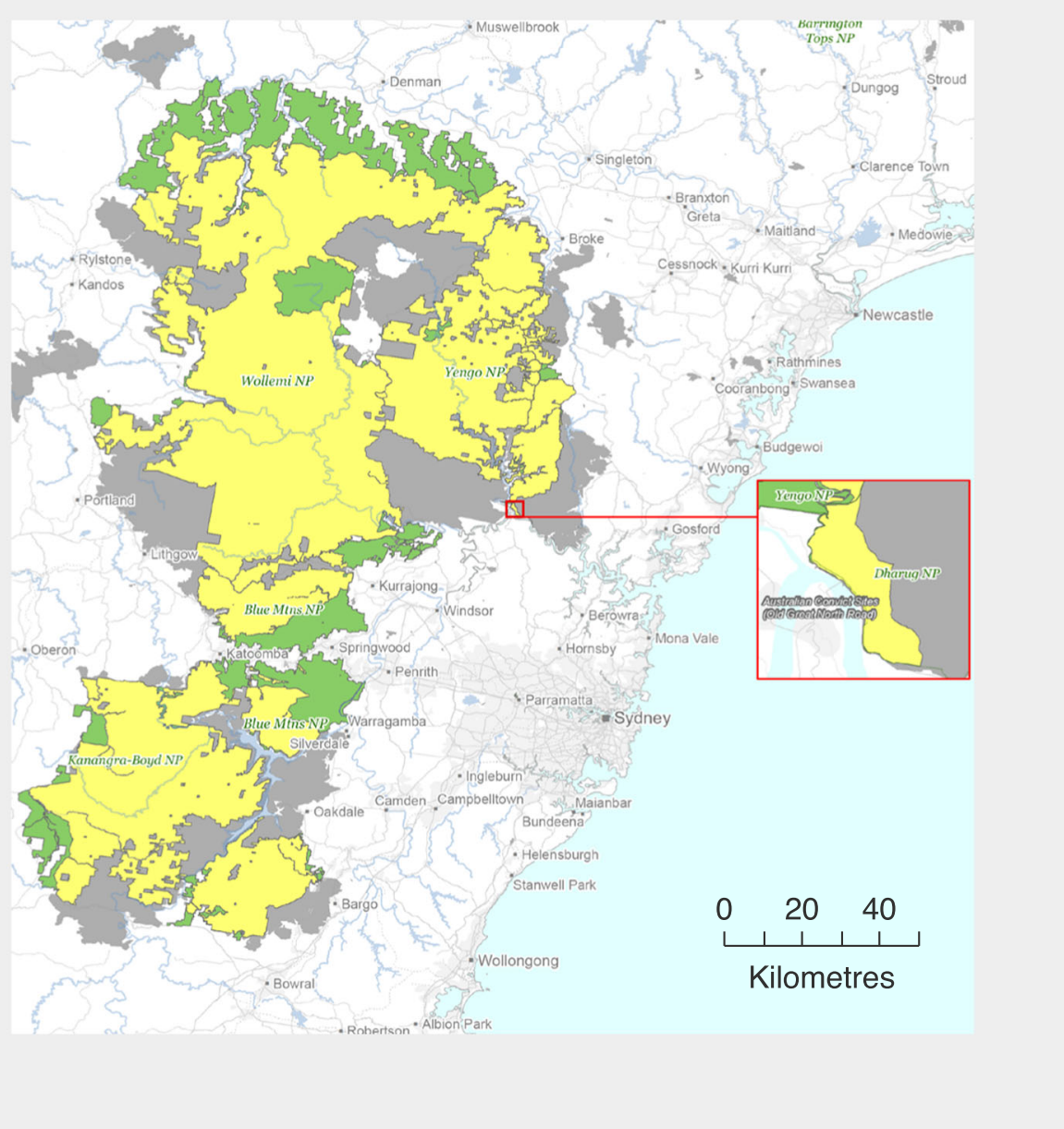

Fig. 3 Area burned in the Blue Mountains World Heritage area. Yellow shows world heritage areas burned, green shows world heritage areas unburned, and grey shows burned areas that are not world heritage. 
concept central to urban sustainability but rarely seen to be associated with peri-urban and rural settlements which were the focus of the Australian apocalypse. Lock-in is where we live in housing that is not only dependent on high levels of power, water and other resources for comfortable living but are part of urban forms that are heavily automobile dependent and hence very oil dependent $^{30-33}$. From the 1950s, this lock-in around fossil fuels and other resources was driven by a mass shift outwards into high consumption suburban living mostly in New World cities but increasingly in Europe ${ }^{34}$. Such low-density urban fabrics have much higher metabolism compared to older dense city centres or transit-oriented corridors ${ }^{35}$ and much policy debate has focussed on the need to consolidate around lower metabolism fabrics, especially for climate mitigation ${ }^{28}$.

The fires in Australia could also be seen as partly due to lock-in as fire management and settlements built in forests are both subject to regulations that were shown to be seriously inadequate. They have highlighted two major issues with respect to climate change. The first is the need to adapt to a future where such fires will likely be increasing, threatening non metropolitan urban communities directly as well as settlements in the bush and forested areas around the cities. The second is how settlements in the burnt areas rebuild in order to be part of the mitigation process required. These issues can be linked as the areas destroyed by fire were in peri-urban and rural settlements that are potentially more resource consumptive and are highly vulnerable to climate change due to their fire exposure ${ }^{36}$.

In Australia the past 50 years has seen a movement to rural and coastal areas with housing that is positioned within forested areas, located a few hours from big cities, called 'sea change' or 'tree change' settlement ${ }^{37}$. Peri-urban development is now $15 \%$ of Australian settlements and rural settlements just $3 \%^{38}$. Such housing is heavily car dependent and often without much sustainability-oriented planning control over its location and issues such as energy and water efficiency or other elements of ecological footprint.

The apocalyptic fires were blamed by some commentators on a lack of prescribed burning, especially around settlements, though this was rejected by many scientists who argued that the fires could have been exacerbated by 'hazard reduction burning', which itself is very damaging to biodiversity and risks nearby settlements ${ }^{39}$. This fire debate has been raging in the academic and public policy arena for many years ${ }^{40-42}$. The threat to settlements is now much more real, prompting a reassessment of more nuanced, small scale approaches that are closer to Indigenous techniques and could be applied in and around settlement areas ${ }^{43,44}$

The core themes of recent IPCC reports that can be applied to the Australian peri-urban and rural settlements, as well as larger urban areas in general, are:

1. Retreat and rebuild: scattered development along coastlines and into forested bush are now very vulnerable and many developments will need to 'retreat' as well as rebuild using new materials and circular economy principles. (See all recent reports from IPCC WG2 on Adaptation).

2. Solar or eco villages: new development will need to be in zero carbon villages which are more compact and built for 2050 zero carbon outcomes in housing and transport as well as having other less resource consumptive features such as water sensitive urban design; they will need to be in locations that are less vulnerable to fires and with landscaping that is also more fire resilient. Such small-scale local technology can be relevant to all developing and developed settlements of any size but need to be demonstrated in ways that are relevant to local conditions. (See chapter 4 in $1.5^{\circ} \mathrm{C}$ Report). Post corona virus recovery programs can feature such cost-effective, job-intensive projects.
3. Forest fire management and urban planning: maintaining the carbon in forests as well as protecting biodiversity needs to be a higher priority in future. Thus, changes in fire management to protect settlements will need to be more ecologically assessed, along with more Indigenous involvement in smaller scale burning regimes. (See Chapter 5 in the $1.5^{\circ} \mathrm{C}$ Report).

4. Equity and sustainability: the need for more agglomeration to provide better services and less car dependence is important to pursue in peri-urban and rural settlements as well as big cities. The scattering of urban development rather than building hamlets or villages is not sustainable or equitable as it is frequently not affordable housing or living. The zero-carbon agenda for houses and transport can alleviate poverty as well as achieving more sustainable outcomes. Such villages can share local solar facilities with solar recharge for electric vehicles, and create better public and active transport. (See chapter 4 in the $1.5^{\circ} \mathrm{C}$ Report and the Transport and Cities chapters in AR5 report).

5. Innovation and flow back to larger urban areas: the rapid rebuilding of such areas can flow back into retrofitting our cities as it can demonstrate the value of such innovation for more sustainable urban outcomes in both adaptation to fire and mitigation of climate change. (See chapter on Cities in AR5).

The Australian bushfires are the miner's canary on climate change $^{45}$ and can begin to demonstrate the above climate resilient development principles in the rebuilding process of fireimpacted settlements. The next section presents a case study showing urban planning's role in presenting the risks and how they had been well understood for many years.

\section{THE APOCALYPSE EXPERIENCED: CASE STUDY OF SOUTHEAST AUSTRALIA \\ Case study of southeast Australia}

During 2013, an Australian government funded research project on 'Coastal urban climate futures in Southeast Australia' was undertaken by an interdisciplinary team of climate scientists, coastal managers, urban planners, economists and health specialists. This earlier national case study is included partly because of its innovative interdisciplinary approach and importantly, as it turns out, its accuracy in predicting what happened in the $2019 / 20$ bushfires $^{46}$.

The study, funded by the 'National Climate Change Adaptation Research Facility', explored possible coastal urban futures to 2030 and beyond ${ }^{47}$. It particularly focussed on seven local coastal areas stretching from Wollongong on the eastern New South Wales coast to Lakes Entrance on the southern Victorian coast of Australia. Coastal planning in the context of climate change was central to this research with the location being precisely in some of the worst Australian fires of 2019/20. The research method comprised the following key approaches: an inductive approach drawing on carefully selected coastal case studies; an integrated approach connecting science, urban planning, governance; a descriptive approach in identifying drivers and scenarios and a temporal dimension of 2030, 2070 and beyond.

The research sought to better connect climate science with local planning and the consideration of local decision makers. Fire was an important consideration along with other major coastal climate risks, particularly coastal inundation, floods and storms. The isolated nature of the coastal communities highlighted barriers to adaptation such as single-road access in the case of an emergency evacuation as well as the relatively high proportion of aging residents in some coastal villages, increasing the vulnerability of residents. 


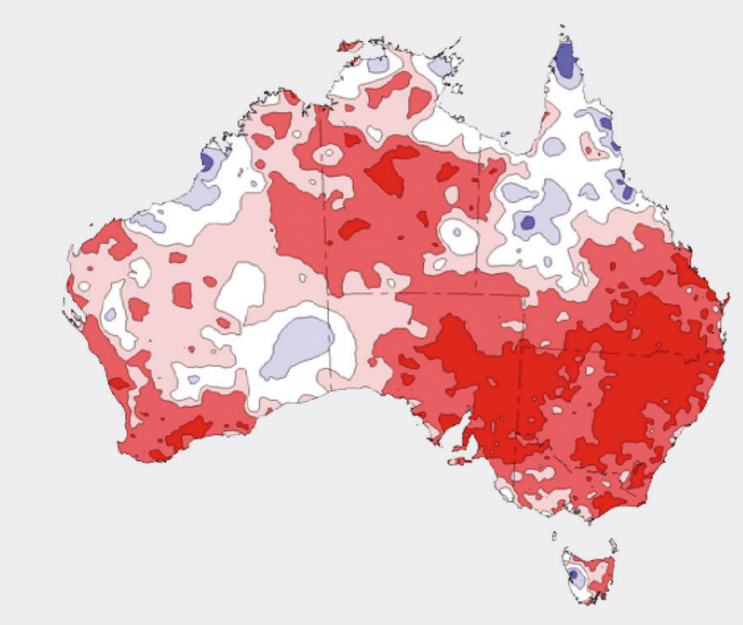

\section{RAINFALL DECILE RANGES}

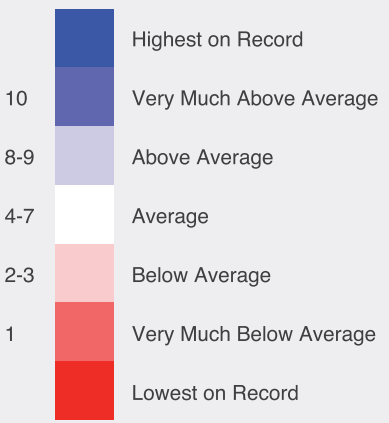

Fig. 4 Australian rainfall deciles - 1 January 2018 to 31 December 2019. The dry conditions that contributed to the size and intensity of the fires came on the back of prolonged rainfall deficiencies across most of southeast Australia, underpinning one of the worst droughts on record.

The South East Coastal Adaptation (SECA) report identified important characteristics of the coastal townships and villages that pointed to future climate risk and vulnerabilities for coastal communities in the near future. This included increased temperatures, further sea level rise, increasing coastal inundation, and the increasing risk of bushfires. Furthermore, small settlements with aging communities are particularly vulnerable due to physical isolation with limited access to public transport, health and other community facilities. This vulnerability could be exacerbated in the future with additional urban development in these settlements coupled with the impacts of climate change. Significant seasonal population fluctuations during summer months exacerbate the challenge of planning effectively for emergencies (see page 4 in ref. ${ }^{47}$ ).

The research concluded with a number of measures that can mitigate future climate risks, recognising the 'business as usual' pattern of urban development discussed above. The SECA study proposed seven principles for a climate-adapted coastal town in 2030, including:

i) an integrated approach should be adopted for sustainable regional and local planning;

ii) the precautionary principle to decision-making should be applied to the location of new and redeveloped urban settlement and infrastructure;

iii) risk management approaches should be incorporated into local and regional strategies for coastal settlements;

iv) appropriate forums should be established at the regional level to enable collaboration;

v) there should be an ongoing process of community engagement;

vi) the skills and knowledge of regional and local communities should be connected (see page 61 in ref. ${ }^{47}$ ).

Seven years later the findings of this report have unfortunately proven to be prescient with the recent catastrophic fires followed immediately by intense flooding, exacerbating the impacts on the natural and built environments. The socio-economic concerns foreshadowed are also now evident with the most recent data indicating a high dependency by the affected communities on social security. There is increasing concern that already vulnerable communities are becoming even more vulnerable to the impacts of climate change with less capacity to adapt to new circumstances ${ }^{48}$.

\section{The Australian government response to climate change}

The Australian government response to climate change since 2013 has been arguably one of systematic dismantling of action on both mitigation and adaptation. This has included the abolition of the Climate Commission, the defunding of the National Climate Adaptation Research Facility and the deskilling on climate science and adaptation in national agencies including the CSIRO and the Federal public service ${ }^{49}$. As a consequence, there has been a general devolving of responsibility to the subnational level, resulting in a patchwork of initiatives rather than an integrated climate response.

Overall, as the climate science has become more definitive ${ }^{2-4,25}$, the Australian climate policy framework has become weaker. The SECA study highlighted that local communities need the support of higher levels of government to 'enable' local actions on both mitigation and adaption as coastal regions are at the forefront of climate risks (inundation, storms, fire exacerbated by drought conditions).

\section{Action on climate change at the subnational level}

In contrast to the lack of national action in Australia, there have been 'stand out' examples of climate change action at the state/ territory and local level as has been found in many other places where weak national policy has been countered with strong city and state policy action ${ }^{2-4,25}$.

The Australian Capital Territory, the home of the national capital Canberra, is located inland in the southeast region. It is a prime example of action on climate change providing hope to communities operating in an environment of negative national governments. It has strong targets of $100 \%$ renewable electricity 
by 2020 (now achieved); carbon neutrality by 2045; and interim emission reduction targets of $40 \%$ by $2020,50-60 \%$ by 2025 , $65-75 \%$ by $2030,90-95 \%$ by 2040 . These have been supported by legislation though few controls have yet happened on peri-urban development or enabling of Eco-Villages. The four key strategic interventions include (i) clear legislated emission reduction targets, (ii) a commitment to renewable energy, (iii) the introduction of rapid transit in the form of light rail, (iv) a commitment to 'living infrastructure' and (v) innovation. Each of these are being discussed publicly in the context of 'adapting an inland national capital to a warmer future ${ }^{50}$. Fire issues will now be firmly on the agenda across all Australian cities after the 2019/ 2020 apocalypse that threatened to engulf Canberra.

\section{APOCALYPSE AVOIDED? SCENARIOS FOR THE FUTURE}

So what does all this mean for Australian settlements in terms of future urban planning in a rapidly changing climate? Two scenarios are suggested.

\section{Scenario 1: business as usual}

Australia returns to 'business as usual' following the fires using traditional approaches in rebuilding settlements and surrounding bushland in peri-urban and coastal areas. There are no special processes that allow communities to express what they want to see in their future as it was decided just to go back to what was. The insurance system and local regulations led to 'lock-in of business as usual' with houses being quickly rebuilt in the same locations and using the same materials and designs approved by councils. The infrastructure for power and water is just patched up as there is no framework from any level of government to guide the installation of new systems that reduce their carbon and water footprint. Roads and petrol stations are rebuilt to encourage fossil fuel-based car use. Economic decline sets into rural areas as people traumatised by the fires refuse to return to settlements that become increasingly expensive due to their fossil-fuel and car dependence. Poverty and violence become more and more characteristic of the forested areas of scattered development. Forest and bushland management remains based on large scale prescribed burning but fails as most areas have become too dry and too hot to undertake such hazard reduction burning safely. Finally, as dry and hot weather intensifies further, another set of fires sweeps through, destroying homes and bushland in new and old areas, sweeping into big cities and causing sever panic and destruction. Australians lose their sense of resilience and concern for others as the future seems out of their control.

\section{Scenario 2: bouncing forward}

Australia decides not to just bounce back, but to bounce forward as good resilient settlements must do, adapting and mitigating as they rebuild ${ }^{22}$. The key responses begin in small demonstrations and rapidly spread into the bushland peri-urban and coastal areas so badly burnt and from there into regional communities nearby and across Australia.

Establishing more sustainable coastal centres with distributed solar power and water: many small towns that were cut off from power by the fires begin to create a $21^{\text {st }}$ century stand-alone power system based on solar and batteries. The coastal centres using donated solar PV and batteries establish distributed micro grids in 100 of the worst hit areas like Cobargo and Goongerah and the new model quickly spreads throughout regional areas rebuilding their energy and water supplies ${ }^{31,51-55}$.

The temporary small systems are evaluated after some testing weather and are found to be better than the previous model as shown in other global disaster recoveries ${ }^{56,57}$. These sustainable coastal centres quickly adopt another role as solar recharge hubs for community batteries, electric cars, bikes and small vans. This enables each rural centre to become free of all fossil fuels for residents and businesses as well as transport systems. People come to live in such villages as they are part of the zero-carbon transition and there is a new mood of hope in the community as they demonstrate leadership. The model quickly spreads across Australia, building on a long history of distributed power and water systems in remote areas. As they become more popular, the technology and governance systems flow into all peri-urban and rural towns and then into the big cities through small scale Citizen Utilities ${ }^{58}$.

Building Eco Villages into Australian cities: the dramatic growth in household solar in Australian urban communities ${ }^{56}$ enjoys an even bigger growth spurt as the peri-urban/rural Eco Village model is copied across urban grids using community-scaled technology with solar, batteries and Solar Recharge Hubs for electro-mobility as well as water sensitive urban design and local citizen utilities. The 2020 s see a complete phasing out of fossil-fuel based power and fuel as households and businesses adopt the new model, driven by cost reductions and the need to respond to climate change and the bushfire apocalypse.

Indigenous burning practices: after the failure of large-scale prescribed burning, the approach demonstrated by Indigenous fire experts in small parts of the landscape, such as Adelaide parklands, begins to take off as it is a more community-based, smaller scale and effective approach ${ }^{42,59}$. The application of this approach to non-metropolitan urban communities then follows. Management of bushland and forested areas of these smaller urban settlements is based on a patchwork of fire-regimes related to the biodiversity, ecology and human uses of each area, making them less susceptible to large-scale wildfires ${ }^{44,60}$.

Re-thinking our peri-urban/rural towns: the need for resilience to be built into all town planning and the consciousness of rural communities post the apocalypse makes it easier to replace the scattered approach to housing in vulnerable areas around the big cities and along coastlines, rivers and into forests. The focus is now on compact housing where Eco Villages are facilitated and other services can be better provided. New Towns along major train lines are built using the Eco Village model with strong resilience features and possible wider lessons for larger urban centres. Australians begin to see a better future is possible to rise out of the ashes of the apocalypse.

\section{APOCALYPSE AVOIDED: CONCLUSIONS FOR URBAN SUSTAINABILITY}

The Apocalyptic beginning to 2020 commencing with the Australian bushfires followed by hail storms, floods and most recently the COVID-19 virus global pandemic, has stretched everyone in Australia to cope with such a dramatic and continuing assault. We have focussed here on the Australian bushfires but the wider sustainability context cannot be ignored as it challenges many systems, including urban systems and ultimately urban resilience and sustainability ${ }^{61,62}$.

The above brings together three critical fields of researchurban form and structure, climate science, and planning for climate change. It seeks to connect leading global science and urban planning with locally grounded research and what it means now for directly impacted non metropolitan and peri urban communities. This is then seen as a globally important demonstration for urban communities to accelerate their transition away from fossil fuels. The green-shoots of burnt forests in Australia are like the regeneration of urban communities from these demonstrations (Fig. 5).

Overall there must be a combination of factors that come together to prevent the apocalyptic horsemen from mainstreaming and leading to collapse of our urban settlements with the following factors particularly important: 


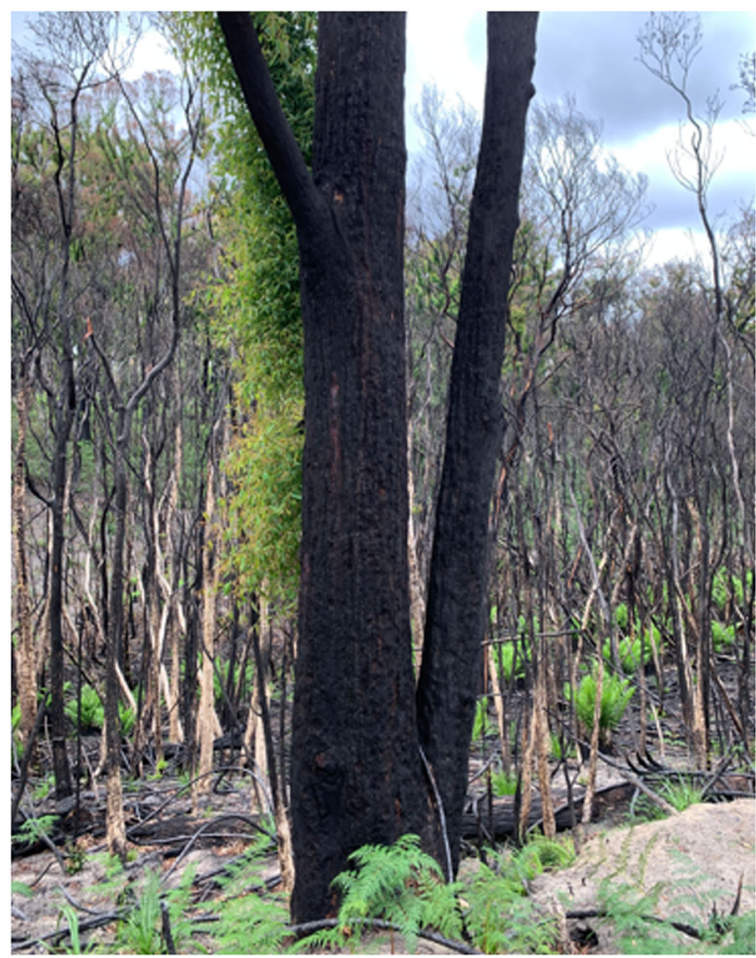

Fig. 5 Green shoots from Australian forests are like green demonstrations from burnt urbanism. Date of photo: 9 March 2020, Place: Genoa, Victoria, Australia (photo taken by Barbara Norman).

1. 'Renewable energy' replacing oil and gas as well as coal. By focussing on a large-scale renewal of peri-urban and rural settlements made vulnerable by the apocalyptic fires, it is possible to create a model for distributed energy and water systems with electrification of transport, that spreads into the cities. Renewable urban centres can lead the world of change to renewable cities. But it can only work if it is combined with urban planning that implements a more integrated approach to action on climate change to reduce emissions and adapt to a changing future; indeed moving towards a regenerative urbanism that creates positive ecological outcomes not just less negative ones ${ }^{63}$.

2. 'Urban sustainability' that can deliver climate responsive urbanism and not the scatter that has locked in such high consumption and poor ecological outcomes. This will mean:

a. Regenerating each urban fabric differently especially in fire-vulnerable small towns;

b. Creating more sustainable urban centres by consolidating ad-hoc development enabling rural concentration, similar to how polycentric development in urban sprawl has been focussed to make less car dependent suburbs ${ }^{64}$.

c. Retreating from risky areas; some settlements in forests should not be rebuilt but rather the forests should be regenerated, increasingly using Indigenous fire management approaches.

d. Co-designing climate change-savvy urban scenarios with communities, as deep changes need deep engagement to develop climate sensitive plans for living infrastructure, urban design, green precincts, place making and heat reduction $^{65,66}$. The potential to re-invent the Volunteer Fire Brigades into ecologically-oriented fire managers working closely with all householders and businesses, as well as with Indigenous experts, on both adaptive and regenerative strategies can be a way to build community as well as address the apocalypse.

3. 'Investment in implementing climate responsive cities' and continuous review of urban management strategies informed by the latest climate science and community needs to ensure that appropriate strategies are implemented in a timely and effective way to minimise risks to urban communities $^{66}$.

The essence of effective urban planning is to manage change in a way that considers the community, the environment and the economy with the aim of developing more sustainable solutions. The impact of climate change is significantly increasing the challenge of managing urban growth. While the focus must remain on reducing emissions, much more consideration needs to be given to working with affected communities experiencing the negative impacts of climate change. Here we provide some insights into the possibilities and the benefits of approaching this global challenge and local challenge of resilience in the face of the apocalypse as confronted Australian settlements in 2019/2020. We suggest that the peri-urban areas and coastal settlements razed by the fires can become a model for climate resilient development that can flow into larger non metropolitan regional centres, bouncing forward in an integrated way, simultaneously responding to climate change and ensuring multiple benefits to urban communities small and large.

\section{DATA AVAILABILITY}

This paper is a synthesis of a wide range of data and information from other sources. Thus, no new datasets were generated or analysed during the current study. The following figshare data record includes the original images presented in Figs. 2 and 5 of the article (taken by the corresponding author Dr. Barbara Norman), and descriptions of the publicly available data sources: https://doi.org/10.6084/m9. figshare. $13114643^{67}$.

Received: 27 March 2020; Accepted: 21 October 2020; Published online: 23 February 2021

\section{REFERENCES}

1. Newman, P. Covid Cities and Climate: historical and potential transitions for the new economy. Urban Sci. 4, 32 (2020).

2. IPCC (Intergovernmental Panel on Climate Change). Climate Change 2001: Synthesis Report. A Contribution of Working Groups I, II, and III to the Third Assessment Report of the Intergovernmental Panel on Climate Change. (eds Watson, R.T. et al.) 398 (2001)

3. IPCC (Intergovernmental Panel on Climate Change). Climate Change 2007: The Physical Science Basis. Contribution of Working Group I to the Fourth Assessment Report of the Intergovernmental Panel on Climate Change. (eds Solomon, S. et al.). 996 (2007).

4. IPCC (Intergovernmental Panel on Climate Change). Climate Change 2014: Synthesis Report. Contribution of Working Groups I, II and III to the Fifth Assessment Report of the Intergovernmental Panel on Climate Change. (eds Pachauri, R.K. \& Meyer, L.A.) 151 (2014).

5. Garnaut, R. The Garnaut Climate Change Review: final report. 634 (Cambridge University Press, 2008).

6. IPSOS, Australians' environmental concerns in January 2020. https://www.ipsos. com/en-au/australians-environmental-concerns-january-2020 (2020).

7. Arriagada, N., Palmer, A., Bowman, D., Morgan, G., Jalaludin, B. \& Johnston, F. Unprecedented smoke-related health burden associated with the 2019-20 bushfires in Eastern Australia. Med. J. Aus. 213, 2 (2020).

8. Australian Parliament, Evidence of the National Bushfire Recovery Agency. Finance and Public Administration Legislation Committee Senate Committee. 2 March 2020 Estimates Proof, Parliament of Australia (2020). 
9. Biddle, N., Edwards, B., Herz, D., \& Makkai, T. Exposure and the Impact on Attitudes of the 2019-20 Australian Bushfires. (Australian National University Centre for Social Research and Methods) (2020).

10. Dickman, C. More than one billion animals killed in Australian bushfires. https:// www.sydney.edu.au/news-opinion/news/2020/01/08/australian-bushfires-morethan-one-billion-animals-impacted.html (2020).

11. Remeikis, A. Canberra chokes on world's worst air quality as city all but shut down. The Guardian. https://www.theguardian.com/australia-news/2020/jan/ 03/canberra-chokes-on-worlds-worst-air-quality-as-city-all-but-shut-down (2020).

12. Smith, E. \& Burkle, F. Collective trauma is real and could hamper Australian communities' bushfire recovery. The Conversation. https://theconversation.com/ collective-trauma-is-real-and-could-hamper-australian-communities-bushfirerecovery-131555 (2020).

13. Norman, B. Are autonomous cities our urban future? Nat. Commun. 9, 2111 (2018).

14. Thomson, G., Newton, P. \& Newman, P. Urban regeneration and urban fabrics in Australian cities. J. Urban Regen. Renew. 10, 1-22 (2016).

15. Diamond, J. Collapse: How Societies Choose to Fail or Succeed. 575 (Viking, 2005).

16. Steffen, W et al. Planetary boundaries: guiding human development on a changing planet. Science. https://doi.org/10.1126/science.1259855 (2015).

17. Meyer, K. \& Newman, P. Planetary Accounting, 21 (Springer, 2020).

18. Climate Council of Australia, Summer of Crisis. https://www.climatecouncil.org.au/ resources/summer-of-crisis/ (2020).

19. Boer, M. M., Resco de Dios, V. \& Bradstock, R. A. Unprecedented burn area of Australian mega forest fires. Nat. Clim. Chang. 10, 171-172 (2020).

20. BoM (Bureau of Meteorology (Australia)), Annual climate statement 2019. http:// www.bom.gov.au/climate/current/annual/aus/ (2020).

21. BoM (Bureau of Meteorology (Australia)), Australian rainfall deciles in December 2019. http://www.bom.gov.au/climate/current/month/aus/archive/201912.summary. shtml (2020).

22. Newman, P., Beatley, T. \& Boyer, H. Resilient Cities: Overcoming Fossil Fuel Dependence, 220 (Island Press, 2017).

23. Cai, W. et al. Increased frequency of extreme indian ocean dipole events due to greenhouse warming. Nature 510, 254-258 (2014).

24. Abram, N. J. et al. Coupling of Indo-Pacific climate variability over the last millennium. Nature 579, 385-392 (2020).

25. CSIRO (Commonwealth Scientific and Industrial Research Organisation (Australia)) and BoM (Bureau of Meteorology (Australia)). Climate Change in Australia -Technical Report. 216 (CSIRO and Bureau of Meteorology, Melbourne, 2015).

26. CSIRO (Commonwealth Scientific and Industrial Research Organisation (Australia)) and BoM (Bureau of Meteorology (Australia)). State of the Climate 2016. 22 (CSIRO and Bureau of Meteorology, Melbourne, 2016).

27. IPCC (Intergovernmental Panel on Climate Change). Climate Change 2014: Mitigation of Climate Change. A Contribution of Working Group III to the Fifth Assessment Report of the Intergovernmental Panel on Climate Change. (eds Edenhofer, O., R. et al.) 1465 (2014).

28. IPCC (Intergovernmental Panel on Climate Change). Global warming of $1.5^{\circ} \mathrm{C}$. An IPCC Special Report on the Impacts of Global warming of $1.5^{\circ} \mathrm{C}$ Above Pre-industrial levels and Related Global Greenhouse Gas Emission Pathways, in the Context of Strengthening the Global Response to the Threat of Climate Change, Sustainable Development, and Efforts to Eradicate Poverty, (eds Masson-Delmotte, V., P. et al.) 616 (2018).

29. C40 Cities Climate Leadership Group \& Global Covenant of Mayors. Summary for Urban Policy Makers: What the IPCC special report on global warming of $1.5^{\circ} \mathrm{C}$ means for cities, 30. https://www.ccacoalition.org/en/resources/summary-urbanpolicy-makers-what-ipcc-special-report-global-warming-15\%C2\%B0c-meanscities (2018).

30. Newman, P.W.G. \& Kenworthy, J.R. Cities and Automobile Dependence, an International Sourcebook, 388 (Gower, 1989).

31. Newman, P.W.G. \& Kenworthy, J.R. Sustainability and Cities: Overcoming Automobile Dependence, 442 (Island Press, 1999).

32. Newman, P. \& Kenworthy, J. The End of Automobile Dependence: How Cities are Moving Beyond Car-based Planning, 300 (Island Press, 2015).

33. Urry, J. The system of automobility. Theory Cult. Soc. 21, 25-39 (2004).

34. Piorr, A., Ravetz, J. \& Tosics, I. (eds). Peri-urbanization in Europe. 142 (University of Copenhagen/Academic Books Life Sciences, 2011).

35. Thomson, G. \& Newman, P. Urban fabrics and urban metabolism: from sustainable to regenerative cities. Resour. Conserv. Recy. 132, 218-229 (2018).

36. Norman, B. \& Gurran, N. Adapting to long term coastal climate risk through planning approaches and instruments. CoastAdapt Information Manual 5, 3rd ed, 31 (National Climate Change Adaptation Research Facility, 2018).

37. Osbaldiston, T. Seeking Authenticity in Place, Culture, and the Self: The Great Urban Escape. 175 (Springer, 2012).
38. Sutton, P., Goetz, A., Fildes, S., Forster, C. \& Ghosh, T. Darkness on the edge of town: mapping urban and peri-urban Australia using nighttime satellite imagery. Prof. Geogr. 62, 119-133 (2009).

39. Ruane, S. Integrating wildfire risk management and spatial planning - A historical review of two Australian planning systems. Int. J. Disaster Risk Reduct. 53. https:// doi.org/10.1016/j.ijdrr.2020.101984 (2021).

40. Bradshaw, S. D., Dixon, K. W., Lambers, H., Cross, A. T., Bailey, J. \& Hopper, S. D. Understanding the long-term impact of prescribed burning in Mediterraneanclimate biodiversity hotspots, with a focus on southwestern Australia. Int. J. Wildland Fire 27, 643-657 (2018).

41. Norman, B., Weir, J., Sullivan, K. \& Lavis, J. Planning and bushfire risk in a changing climate: urban and regional planning systems. 78 (Bushfire Cooperative Research Centre, 2014).

42. Zylstra, P., Hopper, S., Bradshaw, D., Dixon, K. \& Lindenmayer, D. Submission No. NND.001.00262 to the Royal Commission into Natural Disaster Arrangements, Australian Government, 27 (2020).

43. Dixon K. Controlled burns destroy ecosystems and may not reduce fire risk, $A B C$ Science Show. https://www.abc.net.au/radionational/programs/scienceshow/ controlled-burns-destroy-ecosystems-and-may-not-reduce-fire-risk/11774496 (2019).

44. Zylstra, P.J. The unlearned country. Meanjin. https://meanjin.com.au/blog/theunlearned-country/ (2020).

45. Royal Commission into National Natural Disaster Arrangements. (Australia, 2020).

46. Planning Institute of Australia. 2014 National Planning Awards for Excellence. https://www.planning.org.au/awards/2014-national-award-winners. (2014).

47. Norman, B. et al South East Coastal Adaptation: Coastal urban climate futures in SE Australia from Wollongong to Lakes Entrance, 130 (National Climate Change Adaptation Research Facility, 2013).

48. NCOSS (NSW Council of Social Services) Mapping Economic Disadvantage in Fire Affected Communities, 14 (2020).

49. O'Donnell, T. \& Mummery, J. The 2017 budget has axed research to help Australia adapt to climate change. The Conversation. https://theconversation.com/the2017-budget-has-axed-research-to-help-australia-adapt-to-climate-change-77477 (2017).

50. ACT (Australian Capital Territory) Government. ACT Climate Change Strategy for 2019-2025. 140 (Environment, Planning and Sustainable Development Directorate, 2019).

51. Resilient Energy Collective. https://www.resilientenergy.com.au/ (2020).

52. Witchcliffe Eco Village. https://www.ecovillage.net.au/ (2020).

53. Newton, P., Prasad, D., Sproul, A., and White, S. (eds). Decarbonising the Built Environment: Charting the Transition, 555 (Palgrave Macmillan, 2019).

54. Guy, S., Marvin, S., Medd, W. \& Moss, T. Shaping urban infrastructures: intermediaries and the governance of socio-technical networks, 240 (Earthscan, 2011).

55. AEMO (Australian Energy Market Operator). Integrating Utility-scale Renewables and Distributed Energy Resources in the SWIS, 53 (2019).

56. Peter, A. How have Puerto Rico's new microgrids performed during its massive power outage? Fast Company. https://www.fastcompany.com/90450772/howhave-puerto-ricos-new-microgrids-performed-during-its-massive-power-outage (2020).

57. Newman, P. The rise and rise of renewable cities. Renew, Energy Environ. Sust. 2, 10 (2017).

58. Green, J. \& Newman, P. Citizen utilities: the emerging power paradigm. Energy Policy 105, 283-293 (2017).

59. Bowman, D. \& French, B. Our land is burning, and western science does not have all the answers. The Conversation. https://theconversation.com/our-land-is-burningand-western-science-does-not-have-all-the-answers-100331 (2019).

60. Prescribed Burning Conference. http://www.pbc2019.com.au/abstracts.php (2019).

61. Webb, R. et al. Sustainable urban systems: co-design and framing for transformation. Ambio 47, 57-77 (2018).

62. Elmqvist, T. et al. Urban tinkering. Sustain. Sci. 13, 1549-1564 (2018).

63. Thomson, G. \& Newman, P. Geoengineering in the anthropocene through regenerative urbanism. Geosciences 6, 46 (2016).

64. Calthorpe, P. The Next American Metropolis: Ecology, Community, and the American Dream, 160 (Princeton Architectural Press, 1993).

65. Norman, B. Climate Ready Cities. Policy Information Brief 2, 6 (National Climate Change Adaptation Research Facility, 2016).

66. Norman, B. Sustainable Pathways for our Cities and Regions: Planning within Planetary Boundaries, 189 (Routledge, 2018).

67. Norman, Barbara, Newman, Peter, Steffen, Will. Metadata supporting the published article: Apocalypse Now: Australian Bushfires and the Future of Urban Settlements. figshare. https://doi.org/10.6084/m9.figshare.13114643 (2020).

68. Collins, J. J. The Apocalyptic Imagination: An Introduction to Jewish Apocalyptic Literature. 351 (Eerdmans, 1998).

69. Cook, D. Contemporary Muslim Apocalyptic Literature (Religion and Politics), 282 (Syracuse University Press, 2005). 
70. Reddish, M.G. Apocalyptic Literature: A Reader, 352 (Hendrickson, 1998).

71. Cook, S.L. The Apocalyptic Literature: Interpreting Biblical Texts, 234 (Abingdon Press, 2003).

72. Newman, P. in Handbook of Engaged Sustainability, (ed Marques, J.), 297-308 (Springer, 2018).

\section{ADDITIONAL INFORMATION}

Correspondence and requests for materials should be addressed to B.N.

Reprints and permission information is available at http://www.nature.com/ reprints

Publisher's note Springer Nature remains neutral with regard to jurisdictional claims in published maps and institutional affiliations.

\section{AUTHOR CONTRIBUTIONS}

Barbara Norman is the lead and corresponding author with overall responsibility for the article. The content of the article has been shared by the three authors as a group effort with Barbara Norman specifically contributing urban planning, coastal planning and climate change adaptation, Peter Newman specifically contributing urban form, urban climate change mitigation and urban sustainability and Will Steffen contributing Earth System science, global change and ecosystem dynamics.

\section{COMPETING INTERESTS}

The authors declare no competing interests. (i) Open Access This article is licensed under a Creative Commons Attribution 4.0 International License, which permits use, sharing, adaptation, distribution and reproduction in any medium or format, as long as you give appropriate credit to the original author(s) and the source, provide a link to the Creative Commons license, and indicate if changes were made. The images or other third party material in this article are included in the article's Creative Commons license, unless indicated otherwise in a credit line to the material. If material is not included in the article's Creative Commons license and your intended use is not permitted by statutory regulation or exceeds the permitted use, you will need to obtain permission directly from the copyright holder. To view a copy of this license, visit http://creativecommons. org/licenses/by/4.0/.

(C) The Author(s) 2021 